\title{
Balloon expulsion from the rectum in constipation of different types
}

\author{
P R H BARNES AND J E LENNARD-JONES
}

From St Mark's Hospital, London

SUMMARY The defaecatory mechanism using a balloon model with simultaneous measurement of intrarectal pressure has been studied in 15 control subjects with normal bowel habit and in 39 patients with chronic constipation; 31 with a normal barium enema and eight with idiopathic megarectum. Fourteen of those with a normal barium enema had prolonged whole gut transit times as measured by radio-opaque shapes. The ability of the patient to expel a rectal balloon containing 50,100, and $150 \mathrm{ml}$ of water, lying on their side in the left lateral position was tested and if unsuccessful, in the sitting position with the knees raised. All but one of the control subjects could expel balloons in the left lateral position. Only five of 17 constipated patients with normal barium enemas and transit times could expel balloons lying on their side although a further three could do so when sitting. None of 14 patients with slow transit and normal barium enemas could expel balloons in left lateral position although three could do so when sitting. Patients with megarectum could not expel balloons in either position. Levels of intrarectal pressure with straining were not significantly different between controls, who were able to expel balloons, and constipated patients with a normal barium enema, but were greater $(\mathrm{p}<0 \cdot 01)$ in patients with megacolon than in control subjects. Using the balloon model a disorder of the defaecatory mechanism is present in patients with constipation of different types, but this is not because of an inability to raise intrarectal pressure.

The term constipation lacks strict definition but most patients refer to infrequent bowel actions or the difficult passage of hard stool, usually associated with defaecation straining. ${ }^{1}$ Patients described in this paper were those who failed to respond to fibre supplements and other simple measures and required treatment with laxatives, suppositories, or enemas. Many of the patients complained of severe abdominal discomfort, distension, and general malaise to the extent that their health was disrupted.

It is possible to define constipation by the delayed transit of radio-opaque markers around the gastrointestinal tract. ${ }^{2}$ This definition provides a useful physiological classification for constipation. Patients with slow intestinal transit can be separated radiologically into those patients with a megacolon or megarectum and those patients with a normal sized colon. ${ }^{3}$ Other patients with complaints of constipation have normal transit times and normal barium enemas.

While severe constipation is generally assumed to

Address for correspondence: Professor J E Lennard-Jones, St Mark's Hospital, City Road, London EC1V 2PS.

Received for publication 15 November 1984 be related to disturbed colonic motility, several reports suggest that there may be a failure of normal defaecatory function in these patients. ${ }^{4-6}$ We have used a balloon model to study the defaecatory mechanism in 39 patients with constipation of different types and compared the results with a group of 15 patients with normal bowel habit.

\section{Methods}

\section{PATIENTS}

All patients had been referred to St Mark's Hospital with a primary complaint of chronic constipation. Fourteen women had prolonged intestinal transit with a normal barium enema and are described as suffering from idiopathic slow transit constipation. Eight patients (six men, two women) had evidence of a megarectum on barium enema and the rectal width in all these patients was above the normal range $^{3}$ (mean rectal diameter at the pelvic brim on the lateral film was $11 \cdot 0 \pm 2 \cdot 1 \mathrm{~cm}$ ); Hirschsprung's disease was excluded by demonstration of an intact rectosphincteric inhibitory reflex or by a full thickness rectal biopsy. Seventeen patients (16 women 
and one man) had a normal whole gut transit time despite a complaint of chronic constipation and all these patients had a normal barium enema. Fifteen control patients were recruited all of whom reported a bowel frequency of between three motions a day to three motions a week and none admitted to defaecation straining. All had normal barium enemas. Thirteen were attending for colonoscopy for removal of colonic polyps or for polyp follow up, one had Crohn's disease of the terminal ileum and one had anal warts.

Intestinal transit rate was measured using a modification of the method described by Hinton, Lennard-Jones, and Young. ${ }^{2}$ Laxatives, suppositories or enemas were stopped two days before the start of the study and during the study period. Each patient took 20 solid radio-opaque markers by mouth and five days later a plain abdominal radiograph was taken. Those who had failed to excrete $16(80 \%)$ of the markers were regarded as having a slow whole gut transit time.

A soft rubber balloon (London Rubber Co) was attached to one end of a $10 \mathrm{~cm}$ length of plastic tubing and a three way tap was inserted at the other. On distension with 50,100 , or $150 \mathrm{cc}$ water, the balloon assumed an ellipsoid shape with maximum diameters of $3.5,4.5$, and $6.5 \mathrm{~cm}$ respectively. The intraluminal pressure with the three volumes was 36 , 56 and $64 \mathrm{~cm}$ of water respectively. Radiographs of the balloon filled with barium revealed that in the rectum it assumed a more cylindrical shape and attempts at defaecation straining caused no marked change in its shape.

The patient lay on the left side with the knees drawn up towards the chest and the well lubricated balloon was inserted into the rectum. Water was injected in three $50 \mathrm{ml}$ increments and after each increment the patient was encouraged to make a maximum effort to expel the balloon. If the balloon could not be expelled in the left lateral position, the patient sat on a modified commode chair with the knees raised and the test was repeated.

Intrarectal pressure outside the balloon was measured during each straining attempt using a water filled ureteric catheter fitted at its distal end with a $4 \mathrm{~mm}$ micro-balloon placed at the level of the maximum balloon diameter. The catheter was attached via a pressure transducer to a Devices recording machine. Pressure rise was taken above a baseline of resting intrarectal pressure at each volume.

\section{Results}

BALLOON EXPLUSION (TABLE 1)

All but one of the control subjects were able to
Table 1 Number of subjects in each group who were able to expel a balloon in two different postures

\begin{tabular}{|c|c|c|c|c|}
\hline & $\begin{array}{l}\text { Normal } \\
\text { subjects }\end{array}$ & Megarectum & $\begin{array}{l}\text { Slow transit } \\
\text { constipation }\end{array}$ & $\begin{array}{l}\text { Normal transit } \\
\text { constipation }\end{array}$ \\
\hline $\begin{array}{l}\text { No. } \\
\text { Left lateral }\end{array}$ & $(15)$ & (8) & (14) & (17) \\
\hline position & 14 & $0^{*}$ & $0^{*}$ & $5^{*}$ \\
\hline $\begin{array}{l}\text { Sitting } \\
\text { position }\end{array}$ & NT & 0 & 3 & 8 \\
\hline
\end{tabular}

${ }^{*}(p<0 \cdot 001)$. NT $=$ Not tested.

expel all of the balloons in the left lateral position. None of the patients with megarectum could expel balloons in either position. None of the patients with idiopathic slow transit constipation could expel balloons in the left lateral position although three could do so when sitting. Five of 17 patients with a normal transit time could expel balloons in the left lateral position and a further three could expel balloons when sitting. In the left lateral position balloon expulsion was significantly impaired in all three patient groups as compared with controls using Fisher's exact test $(p<0.001)$.

EFFECT OF BALLOON SIZE (TABLE 2)

Control subjects were able to expel balloons of 50 , $100,150 \mathrm{cc}$. In the slow transit group all three patients who were able to expel balloons while sitting did so with the $50 \mathrm{cc}$ balloon but only two were able to expel larger balloons. In patients with a normal transit time those able to expel balloons in the left lateral position could do so with all volumes tested; in the sitting position two further patients were able to expel a $50 \mathrm{cc}$ balloon but not those of larger volumes.

INTRARECTAL PRESSURE (TABLE 3)

Mean intrarectal pressure in the 14 normal subjects able to expel balloons was $107 \mathrm{~cm} \mathrm{H}_{2} \mathrm{O}$ with a wide

Table 2 Number of subjects able to expel balloons of different size in two different postures

\begin{tabular}{lllll}
\hline & & \multicolumn{3}{l}{ Balloon size $(\mathrm{ml})$} \\
\cline { 3 - 5 } Subject & Posture & 50 & 100 & 150 \\
\hline Normal & $\mathrm{L}$ & 14 & 14 & 14 \\
(15) & $\mathrm{S}$ & $\mathrm{NT}$ & $\mathrm{NT}$ & $\mathrm{NT}$ \\
Slow transit & $\mathrm{L}$ & 0 & 0 & 0 \\
(14) & $\mathrm{S}$ & 3 & 1 & 1 \\
Normal transit & $\mathrm{L}$ & 5 & 5 & 5 \\
(17) & $\mathrm{S}$ & 8 & 6 & 6 \\
\hline
\end{tabular}

L=lateral, $S=$ sitting, NT= not tested. 
Table 3 Intrarectal pressure during straining in the four groups of subjects

\begin{tabular}{|c|c|c|c|c|}
\hline & $\begin{array}{l}\text { Normal } \\
\text { subjects }\end{array}$ & Megarectum & $\begin{array}{l}\text { Slow transit } \\
\text { constipation }\end{array}$ & $\begin{array}{l}\text { Normal transit } \\
\text { constipation }\end{array}$ \\
\hline \multirow{3}{*}{$\begin{array}{l}\text { No } \\
\text { Left lateral } \\
\text { position } \\
\text { Sitting } \\
\quad \text { position }\end{array}$} & 15 & 8 & 14 & 17 \\
\hline & $107 \pm 43^{*}$ & $175 \pm 60^{*}$ & $90 \pm 37$ & $96 \pm 32$ \\
\hline & NT & $178 \pm 65$ & $134 \pm 38$ & $103 \pm 33$ \\
\hline
\end{tabular}

$(\mathrm{p}<0.01)$

For each subject the mean of three tests $\left(\mathrm{cm} / \mathrm{H}_{2} \mathrm{O}\right)$, each with a balloon of increasing volume has been taken. Figures shown are the mean $+\mathrm{SD}$ for all the patients in each group.

standard deviation. The single normal subject who was unable to expel a rectal balloon developed intrarectal pressure of $120 \mathrm{~cm} \mathrm{H}_{2} \mathrm{O}$ during straining attempts. No differences could be shown between levels of intrarectal pressure achieved in either group of patients with a normal barium enema and controls. Patients with megarectum achieved higher intrarectal pressures than control subjects $(p<0 \cdot 01)$ despite their inability to expel the balloon.

\section{Discussion}

It is now possible to define different groups of patients complaining of constipation by measurement of whole gut transit rate $^{2}$ and rectal size. ${ }^{3}$ Patients with idiopathic megacolon and megarectum complain of constipation frequently associated with soiling which usually dates back to childhood. Intervals of weeks to months may occur between bowel actions. Men are equally represented in this group but whether it is a congenital or acquired disorder is unknown. Patients with a slow whole gut transit rate and normal barium enemas (idiopathic slow transit constipation) are exclusively female. Constipation usually begins in adolescence though it may begin in childhood or suddenly after abdominal or pelvic surgery. Intervals of several weeks may occur between bowel actions; abdominal distension and pain are prominent features. Those with a normal barium enema and transit rate are predominantly women; defaecation straining, a sense of incomplete rectal evacuation, abdominal pain, and distension are common associated symptoms.

Factors producing constipation in these three clinical groups may well differ but failure to expel a water filled balloon from the rectum appears to be a feature they have in common. This failure is not because of an inability to raise intrarectal pressure because this was not reduced in any patient group as compared with the control subjects. The higher levels of intrarectal pressure shown in megabowel patients may be explained by the predominance of fit young men in this group.

In general, patients able to expel balloons all did so with the $50 \mathrm{ml}$ balloon but a few patients were unable to expel the larger balloons. Patients with a normal barium enema are aware of a $50 \mathrm{cc}$ balloon and most experience a typical call to stool when the volume is increased to $150 \mathrm{cc}$. Most normal subjects are able to expel balloons in the left lateral position but some constipated patients can only do so in the sitting position.

Normal defaecation in man comprises synchronised autonomic and voluntary functions which are still poorly understood. ${ }^{7}$ It is postulated that a distending faecal bolus enters the rectum by peristalsis and produces a series of responses initiated by sensory receptors within the rectal wall and in the pelvic floor muscles. Central transmission of sensory inputs allows conscious recognition of rectal fullness. Rectal distension causes reflex inhibition of the internal anal sphincter ${ }^{8}$ (rectosphincteric reflex) via the myenteric plexus ${ }^{9}$ thus lowering anal canal pressure.

The puborectalis muscle and striated external anal sphincter (voluntary sphincters) which normally exhibit tonic activity at rest and during sleep, ${ }^{10}$ contract reflexly upon rectal distension to maintain continence $^{11}$ (inflation reflex). During normal defaecation the voluntary sphincters are inhibited ${ }^{12}$ through reflex or cortical pathways, ${ }^{13}$ via the pudendal nerve and branches of $S_{3}$ and $S_{4}$ motor roots (which supply puborectalis direct). ${ }^{14}$ Relaxation of the puborectalis widens and lowers the anorectal angle, obliterating the flap valve effect and inhibition of the external anal sphincter further relaxes the anal canal. Increases in intra-abdominal pressure, probably associated with rectosigmoid peristalsis allows rectal evacuation.

Failure of balloon expulsion must be explained in terms of disordered physiology. It is recognised that the balloon model described probably lacks any component of peristaltic activity by the sigmoid colon. In other respects it fulfills many of the features of normal defaecation. The left lateral position chosen for the initial test is not physiological but it is clinically convenient. In practice almost all normal subjects can expel a balloon in this position. All patients tested had a positive rectosphincteric reflex confirming normal relaxation of the smooth muscle of the internal anal sphincter upon rectal distension. Although patients with constipation of different types may have different levels of resting tone in the internal sphincter, ${ }^{15}$ it seems unlikely that dysfunction of this sphincter could account for failure of balloon explusion because the levels of intrarectal pressure observed 
usually exceeded the normal resting anal canal pressures $\left(<100 \mathrm{~cm} \mathrm{H}_{2} \mathrm{O}\right)$ and the sphincter would have been inhibited by the rectal distension.

Failure of normal inhibition of the voluntary sphincter mechanism would seem a more probable explanation of the patients failure to expel rectal balloons observed in this study. Other studies have shown by pressure measurement within the anal canal and by electromyography of the puborectalis muscle that active contraction of the striated muscle occurs when women with idiopathic slow transit constipation strain and fail to expel a balloon. ${ }^{16}$ Electromyographic assessment of patients in this study has confirmed that a paradoxical contraction of the puborectalis muscle occurs on defaecation straining in patients unable to expel a balloon. Whether this is because of a disturbed spinal reflex or is produced by central efferents is not known. Similar lack of inhibition and indeed paradoxical contraction of the puborectalis muscle has been observed in other pelvic floor disorders associated with defaecation straining ${ }^{17}$ and failed sphincteric inhibition has been cited as a cause of idiopathic megarectum. ${ }^{18}$

\section{References}

1 Moore-Gillon V. Constipation: what does the patient mean? J R Soc Med 1984; 77: 108-10.

2 Hinton JM, Lennard-Jones JE, Young AC. A new method for studying gut transit times using radio opaque markers. Gut 1969; 10: 842-7.

3 Preston DM, Lennard-Jones JE, Thomas DM. Towards a radiologic definition of idiopathic megacolon. Gastrointest Radiol 1985; 10: 167-9.
4 Lockhart-Mummery JP. In: Diseases of the rectum and their surgical treatment. London: Bailliere, Tindall, and Cox, 1934: 179-80.

5 Martelli H, Devroede G, Arhan P, Duguay C. Mechanism of idiopathic constipation: outlet obstruction. Gastroenterology 1978; 75: 623-31.

6 Preston DM, Lennard-Jones JE, Thomas BM. The balloon proctogram. Br J Surg 1984; 71: 29-32.

7 Scharli AF, Kiesewetter WB. Defaecation and Continence: some new concepts. Dis Colon Rectum 1970; 13: 81-107.

8 Denny-Brown D, Robertson G. An investigation of the nervous control of defaecation. Brain 1935; 58: 256310.

9 Lane RHS, Parks AG. Function of the anal sphincters following coloanal anastomosis. Br J Surg 1977; 64: 596-9.

10 Floyd WF, Walls EW. Electromyography of the sphincter ani externus in man. $J$ Physiol 1953; 122: 599-609.

11 Ihre T. Studies on anal function in continent and incontinent patients. Scand J Gastroenterol 1974; 9: suppl. 25.

12 Parks AG, Porter NH, Melzak J. Experimental study of the reflex mechanisms controlling the muscles of the pelvic floor. Dis Colon Rectum 1962; 5: 407-14.

13 Frenckner B. Function of the anal sphincters in spinal man. Gut 1975; 16: 638-44.

14 Percy JP, Neill ME, Swash M, Parks AG. Electrophysiological study of the motor nerve supply of the pelvic floor. Lancet 1981; 1: 16-7.

15 Baldi F, Ferrarini F, Corinaldesi $R$ et al. Function of the internal anal sphincter and rectal sensitivity in idiopathic constipation. Digestion 1982; 24: 14-22.

16 Preston DM, Lennard-Jones JE. Anismus in Chronic Constipation. Dig Dis Sci 1985; 30: 413-8.

17 Rutter KRP. Electromyographic changes in certain pelvic floor abnormalities. Proc $R$ Soc Med 1974; 67: 53-6.

18 Todd IP. Discussion on megacolon and megarectum with the emphasis on conditions other than Hirschsprung's Disease. Proc R Soc Med 1961; 54: 1035-7. 